\title{
Arsenic Precipitation in the Bioleaching of Realgar Using Acidithiobacillus ferrooxidans
}

\author{
Peng Chen, ${ }^{1,2}$ Lei Yan, ${ }^{3}$ Qiang Wang, ${ }^{4}$ and Hongyu $\mathrm{Li}^{2}$ \\ ${ }^{1}$ Gansu Institute of Business and Technology (GIBT), Yannan Road No. 18, Lanzhou 730010, China \\ ${ }^{2}$ School of Pharmacy, Lanzhou University, West Donggang Road No. 199, Lanzhou 730020, China \\ ${ }^{3}$ College of Life Science and Technology, Heilongjiang Bayi Agricultural University, Daqing 163319, China \\ ${ }^{4}$ College of Chemistry and Chemical Engineering, Lanzhou University, Tianshui Road No. 222, Lanzhou 730000, China
}

Correspondence should be addressed to Hongyu Li; lihy@lzu.edu.cn

Received 25 March 2013; Revised 13 June 2013; Accepted 19 June 2013

Academic Editor: Xu Zhi Ping

Copyright (C) 2013 Peng Chen et al. This is an open access article distributed under the Creative Commons Attribution License, which permits unrestricted use, distribution, and reproduction in any medium, provided the original work is properly cited.

\begin{abstract}
The current study investigates the characteristics of arsenic precipitation during the bioleaching of realgar. The bioleaching performance of Acidithiobacillus ferrooxidans BY-3 (A.ferrooxidans) was investigated through scanning electron microscopy (SEM), transmission electron microscopy (TEM), X-ray diffraction (XRD), and Fourier transform infrared (FT-IR) spectrophotometry. SEM and XRD analyses revealed that the arsenic-adapted strain of A. ferrooxidans was more hydrophobic and showed higher attachment efficiency to realgar compared with the wild strain. The arsenic precipitation using A. ferrooxidans resulted in the precipitation of an arsenic-rich compound on the surface of the bacterial cell, as shown in the TEM images. The FT-IR spectra suggested that the $-\mathrm{OH}$ and $-\mathrm{NH}$ groups were closely involved in the biosorption process. The observations above strongly suggest that the cell surface of $A$. ferrooxidans plays a role in the induction of arsenic tolerance during the bioleaching of realgar.
\end{abstract}

\section{Introduction}

Realgar, which has a chemical formula of $\alpha-\mathrm{As}_{4} \mathrm{~S}_{4}$, is a sulfide mineral with high arsenic content (over $90 \% \mathrm{As}_{4} \mathrm{~S}_{4}$ ) and has been widely used as a traditional Chinese herbal medicine [1]. However, realgar is not soluble in water, and thus, pretreatment is frequently required to enhance its solubility and/or to prepare it in an appropriate form for clinical use. Recent considerable efforts have focused on developing protocols to increase the solubility and bioavailability of realgar. Among the protocols, bioleaching, which is a simple and effective technology in hydrometallurgy, has attracted extensive interests [2]. For instance, our group previously succeeded in developing a bio-arsenic aqueous solution from realgar particles by taking advantage of an arsenicresistant indigenous strain of $A$. ferrooxidans BY- 3 using the bioleaching method and confirmed the anticancer activities of the developed bioarsenic aqueous solution in vitro and in vivo [3].

On the other hand, arsenic is known to be poisonous for many organisms [4]. A high concentration of arsenic in the leaching solution could inhibit bacterial growth and activity, which have negative effects on realgar bioleaching. Based on our previous observations during the entire bioleaching process [3], the concentration of arsenic interestingly increased to a peak value at first and then decreased, instead of increasing continuously, but there have been no thorough studies on this reason for this phenomenon. The decrease in arsenic concentration may be attributed to the arsenic adsorption and/or precipitation. So far little is known about the arsenic adsorption and/or precipitation in the bioleaching of realgar.

Previous studies have shown that arsenic ions in aqueous solutions can be adsorbed on iron-based adsorbents (via chemical, electrochemical, and physicochemical processes) $[5,6]$ or on microorganisms (via biosorption, bioprecipitation, bioaccumulation, and biotransformation) [7, 8]. Even though bacterial cells are known to play important roles in bioleaching, the surface properties of $A$. ferrooxidans with reference to arsenic tolerance and their function under high arsenic concentrations remain unclear. In addition, there is little information on arsenic mobility during the 
bioleaching of realgar using $A$. ferrooxidans in the presence of ferrous iron. Therefore, the current study aims to investigate arsenic precipitation using the combination of $A$. ferrooxidans and ferric iron compounds and to investigate the surface properties of $A$. ferrooxidans cell response to arsenic.

\section{Materials and Methods}

2.1. Mineral. The investigation was conducted using realgar $\mathrm{As}_{4} \mathrm{~S}_{4}$ (99.01\% pure, Shimen County of Hunan Province, China). The raw realgar was ground to -200 and +300 mesh sizes (approximately $75 \pm 10 \mu \mathrm{m}$ ) and was purified using traditional methods according to the Chinese Pharmacopeia [9]. The mineral was analyzed chemically and mineralogically using an inductively coupled plasma atomic emission spectroscopy (ICP-AES, IRIS Advantage, Thermo Jarrell Ash Corporation, USA) and X-ray diffraction (XRD), respectively. The sample mainly contained realgar (97\%, w/w) with very small inclusions of arsenolite (3\%, w/w). The chemical analysis on the sample showed the following (\%, w/w) metal contents: As (68.0), S (31.01), Fe (0.040), and Ca (0.011) [3].

2.2. Microorganism. The native strain of A. ferrooxidans, which was isolated from an abandoned copper mine in Baiyin, Gansu Province, China, was named BY-3 (CCTCCM203071). The identities of the isolates were confirmed by phylogenetic analyses of $16 \mathrm{~S}$ rRNA gene sequences and the 16S-23S intergenic spacer regions (GenBank accession numbers are DQ676505). The wild strain of $A$. ferrooxidans was adapted to successive increasing concentrations of the realgar in $9 \mathrm{~K}$ medium in a continuous mode [10]. As a consequence, the arsenic-adapted strain A. ferrooxidans BY3 , which was able to tolerate up to $680 \mathrm{mg} / \mathrm{L}$ of As (III), was used to convert raw realgar into an aqueous solution [3]. Bioleaching was performed in a $250 \mathrm{~mL}$ Erlenmeyer flask containing $100 \mathrm{~mL}$ distilled water and $4.469 \mathrm{~g}$ of $\mathrm{FeSO}_{4} \cdot 7 \mathrm{H}_{2} \mathrm{O}$ and $0.5 \mathrm{~g}$ of realgar with an initial $\mathrm{pH}$ value of 1.7 on a rotary shaker at $150 \mathrm{rpm}$ and a constant temperature of $30^{\circ} \mathrm{C}$. The control experiment was performed under similar conditions without realgar.

2.3. Analysis. The experiments lasted for 30 days. Arsenic concentrations were measured by an inductively coupled plasma atomic emission spectroscope (ICP-AES, IRIS Advantage, Thermo Jarrell Ash Corporation, USA). The sample preparation method for ICP-AES analysis was previously described [3]. All experiments were performed in duplicate at a minimum, and the average values were reported. The cell surface properties of $A$. ferrooxidans coated with gold after bioleaching were identified through JEOL field-emission scanning electron microscopy (FESEM, JSM-6701F, Japan) operated at $5 \mathrm{kV}$ to $10 \mathrm{kV}$, and the images were captured using an image slave software. The microscopic features of $A$. ferrooxidans were observed through JEOL transmission electron spectroscopy (TEM; JEM-1230, Japan) operated at $100 \mathrm{kV}$ and an FEI high-resolution transmission electron microscopy (HR-TEM; Tecnai F30, Japan) operated at $300 \mathrm{kV}$. The sample preparation method for the TEM analysis was previously described [11]. The powder XRD analyses of $A$. ferrooxidans in the media with and without realgar were conducted on a multipurpose X-ray diffraction system (X'Pert-Pro MPD, Philips) with $\mathrm{Cu} \mathrm{K} \alpha$ radiation $(\lambda=0.15406 \mathrm{~nm})$ and operated at $40 \mathrm{kV}$ and $40 \mathrm{~mA}$. The vibrational frequency changes on the surface of biomass in the media with and without adsorbed arsenic were detected using a Fourier transform infrared spectrometer (FT-IR) according to the procedures reported by Yan et al. [12].

\section{Results and Discussion}

3.1. Bioleaching of Realgar Using A. ferrooxidans. The realgar bioleaching mechanism was investigated to determine the direct or indirect nature of realgar. Even though defining the predominance of a mechanism is not easy, the importance of cell attachment to the particles to perform bioleaching is widely accepted [13]. Several groups have reported the adhesion of $A$. ferrooxidans to sulphur and mineral surfaces $[13,14]$. In the current study, the SEM image of the surfaces of the realgar particles after bioleaching demonstrated the adhesion behavior of $A$. ferrooxidans, as shown in Figure 1. Moreover, the cell adhesion caused by the interactions of minerals with $A$. ferrooxidans BY-3 has been shown to induce either the hydrophilicity or the hydrophobicity of the minerals and render them floatable or nonfloatable, respectively [14], which is consistent with the results of the current study. In addition, the precipitation of jarosite was visually observed in the process, and the SEM and XRD solid residue patterns confirmed the presence of jarosites. The jarosites on the substrate were expected to prevent direct bacterial action and/or iron (III) attacks. The results above confirmed that $A$. ferrooxidans is essentially attached to the minerals prior to the occurrence of the direct action. Therefore, metabolic energy would be obtained from the constituents released during the dissolution of a solid mineral and subsequently supplied to the suspended bacteria in the solution. The attached and free bacteria might exert combined action on the surfaces of realgar.

3.2. Arsenic Precipitation Using Living A. ferrooxidans Biomass. Following an arsenic precipitation process, the $A$. ferrooxidans biomass was characterized using TEM (Figure 2). The physical integrity of the bacterial cells was maintained at a total arsenic concentration of $680 \mathrm{mg} / \mathrm{L}$. A mass of electron-dense precipitates was clearly observed around the bacterial cells (Figures 2(b) and 2(c)). Further XRD analysis of the isolated precipitates revealed their abundance in arsenic (Figure 3). The above-mentioned results confirmed that arsenicbearing precipitates are attached to bacterial cells, which can adsorb arsenic from a solution. Therefore, these results may explain the concentration reduction of arsenic in the leachate during the bioleaching of realgar. Although the biosorptions of arsenite [iAs (III)], monomethyl arsenate [MMA (V)], and dimethylarsinic acid [DMA (V)] from aqueous solutions have been 


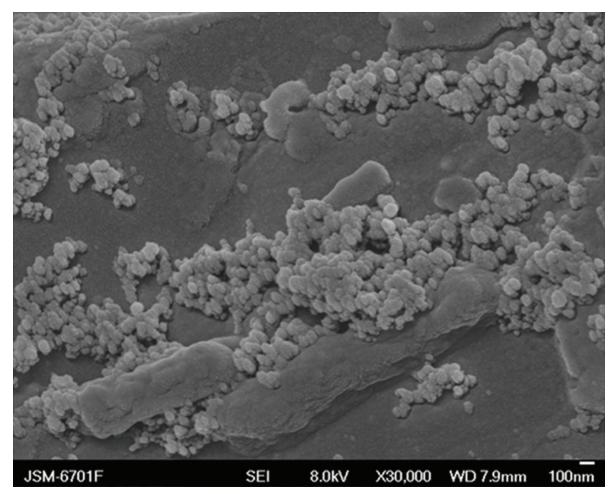

FIGURE 1: SEM image of the surfaces of realgar interactions with $A$. ferrooxidans BY-3 after bioleaching of realgar (scale bar $=100 \mathrm{~nm}$ ).

reported before [12], the arsenic precipitation using living A. ferrooxidans biomass during the bioleaching of realgar that led to arsenic ion accumulation is reported for the first time in the current study. On the other hand, A. ferrooxidans was found capable to efficiently enhance realgar dissolution and remove arsenic from the aqueous solution. Remarkably, these findings are promising for the development of a low-cost realgar pretreatment protocol as a substitute for the existing methodologies.

3.3. Arsenic Precipitation on Ferric Compound. Figure 3(a) shows the XRD patterns of the ferric iron compounds derived from the oxidation of iron (II) using A. ferrooxidans BY-3 in the medium without realgar. Magnetite, jarosite, hydroniumjarosite, and ammoniojarosite were found in the arsenic precipitates. Iron or iron compounds (iron oxides, oxyhydroxides, and hydroxides, including amorphous hydrous ferric oxide $[\mathrm{FeO}-\mathrm{OH}]$, goethite $[\alpha-\mathrm{FeO}-\mathrm{OH}]$, magnetite $[\alpha$ $\left.\mathrm{Fe}_{3} \mathrm{O}_{4}\right]$, and hematite $\left.\left[\alpha-\mathrm{Fe}_{2} \mathrm{O}_{3}\right]\right)$ are the most widely used adsorbents exhibiting high arsenic removal efficiency [15]. Consequently, realgar, mackinawite, ferric arsenate, potassium arsenate, and sodium hydrogen arsenite were observed in the medium with realgar (Figure 3(b)). The changes of arsenic concentration with time in the presence of ferrous iron are shown in Figure S1 (see Supplementary Material available online at http://dx.doi.org/10.1155/2013/424253). During the first 15 days, the arsenic concentrations of the medium with $A$. ferrooxidans $(121 \mathrm{mg} / \mathrm{L})$ were 6.9 times higher than those of the sterile control $(17.59 \mathrm{mg} / \mathrm{L})$. From the 15 th to the 30th day, however, a decrease in arsenic content over time was observed (from $121 \mathrm{mg} / \mathrm{L}$ to $25.56 \mathrm{mg} / \mathrm{L}$ ). These results suggest that the decrease in the extraction of arsenic was due to the uptake of arsenic by adsorbents. A. ferrooxidans efficiently enhances realgar dissolution under experimental conditions, corresponding to the catalysis described in (1). With the direct action of $A$. ferrooxidans used, the dissolution of elemental arsenic was observed during the bioleaching of realgar. Consequently, As (III) mainly exists in the form of $\mathrm{H}_{3} \mathrm{AsO}_{3}$, which can be easily oxidized to As $(\mathrm{V})$ by $A$. ferrooxidans by the reaction described in (2). These assays can be described by the following equations:

$$
\begin{gathered}
\mathrm{As}_{2} \mathrm{~S}_{2}+14 \mathrm{H}_{2} \mathrm{O} \stackrel{\text { A. ferrooxidans }}{\longrightarrow} 2 \mathrm{H}_{3} \mathrm{AsO}_{3} \\
+2 \mathrm{HSO}_{4}^{-}+20 \mathrm{H}^{+}+18 \mathrm{e}^{-} \\
\mathrm{H}_{3} \mathrm{AsO}_{3}+\mathrm{H}_{2} \mathrm{O} \stackrel{\text { A. ferrooxidans }}{\longrightarrow} \mathrm{H}_{3} \mathrm{AsO}_{4}+2 \mathrm{H}^{+}+2 \mathrm{e}^{-}
\end{gathered}
$$

This decrease was due to the generation of iron (III) by the abiotic oxidation of iron (II) described in (3). Furthermore, increasing the concentration of iron (III) enhanced the stimulative effect of iron (III) on realgar oxidation, shown in (3), resulting in the transformation of As (III) into As (V), shown in (2). The above results suggest that the reactions may have occurred as described in (2) and the following:

$$
\begin{gathered}
4 \mathrm{Fe}^{2+}+\mathrm{O}_{2}+4 \mathrm{H}^{+} \stackrel{\text { A. ferrooxidans }}{\longrightarrow} 4 \mathrm{Fe}^{3+}+2 \mathrm{H}_{2} \mathrm{O} \\
\mathrm{As}_{2} \mathrm{~S}_{2}+6 \mathrm{Fe}^{3+} \longrightarrow 2 \mathrm{As}^{3+}+2 \mathrm{~S}_{\text {surface }}^{0}+6 \mathrm{Fe}^{2+} \\
\mathrm{H}_{3} \mathrm{AsO}_{4}+\mathrm{Fe}^{3+} \longrightarrow \mathrm{FeAsO}_{4}+3 \mathrm{H}^{+}
\end{gathered}
$$

Coprecipitation of Fe (III) with arsenic was the main process by which soluble arsenic was partially resorbed by jarosite and magnetite, apart from the biosorption of arsenic from aqueous solution by A. ferrooxidans BY-3 in the bioleaching process. These provide a reasonable explanation as to why the concentration of arsenic was reduced [3].

Therefore, these results indicate that increasing the concentration of ferric iron can enhance the stimulating effect of ferric iron on realgar oxidation, resulting in the transformation of arsenic acid $\left(\mathrm{H}_{3} \mathrm{AsO}_{4}\right)$ into ferric arsenate $\left(\mathrm{FeAsO}_{4}\right)$. Ferric arsenate, which is characterized by two broad diffuse peaks on the XRD pattern, is a common precipitate used in metallurgical industries to control arsenic in effluents [16]. In the current study, ferric arsenate was the major existing form of arsenic precipitation on the ferric compounds in the realgar solutions. Therefore, the variations in the arsenic concentrations in the solutions were due to the occurrence of arsenic precipitation during the bioleaching.

\subsection{Surface Properties of A. ferrooxidans with Reference to} Arsenic Tolerance. FT-IR measurements were further performed to investigate the main functional groups involved in the arsenic biosorption. The peaks at $3301,2926,1655,1539,1452,1236$, and $1079 \mathrm{~cm}^{-1}$ in the FT-IR spectrum of unloaded biosorbent were assigned to the $-\mathrm{OH},-\mathrm{NH}$ groups, and $-\mathrm{CH}_{2}, \mathrm{C}=\mathrm{O}$ stretching, $-\mathrm{NH}$ stretching, $-\mathrm{CH},-\mathrm{SO}_{3}$ stretching, and $-\mathrm{CN}$ stretching vibration groups, respectively (Figure 4(a)). Figure 4(b) shows the changes in the FT-IR spectrum of the biomass after arsenic adsorption. However, the peaks shifted to $3413,2962,1640,1541,1421,1196$, and $1083 \mathrm{~cm}^{-1}$, respectively, after arsenic loading. Since FT-IR spectra exhibited fingerprints of microenvironmental variations, the observed spectral changes vividly reflected that 


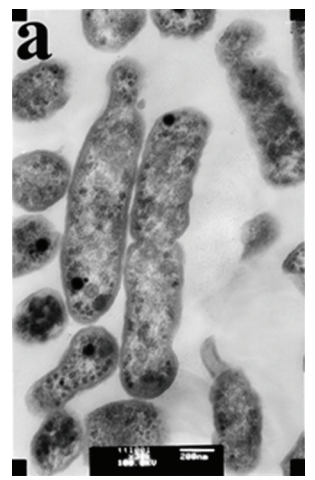

(a) A. ferrooxidans BY-3 in medium without realgar $($ scale bar $=200 \mathrm{~nm})$

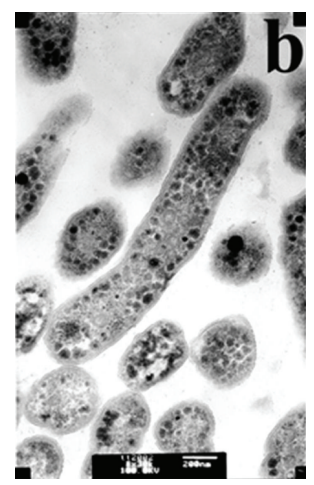

(b) A. ferrooxidans BY3 after the bioleaching of realgar (scale bar $=200$ $\mathrm{nm})$

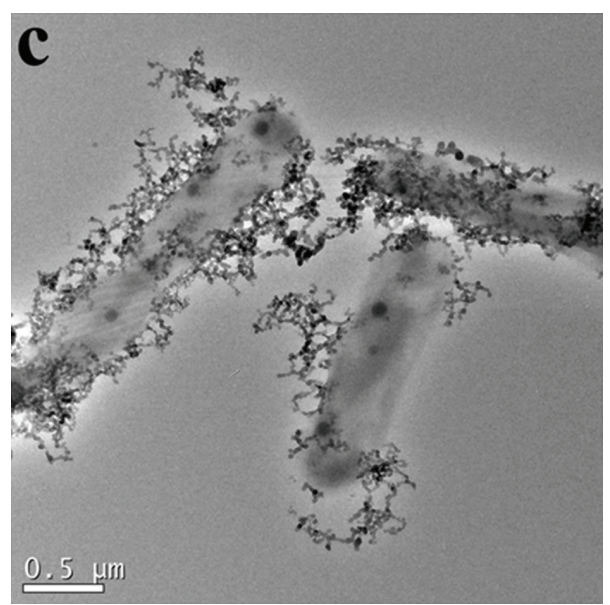

(c) A. ferrooxidans BY-3 after the bioleaching of realgar (scale bar $=0.5 \mu \mathrm{m})$

FIgURE 2: TEM image of A. ferrooxidans BY-3 cells.

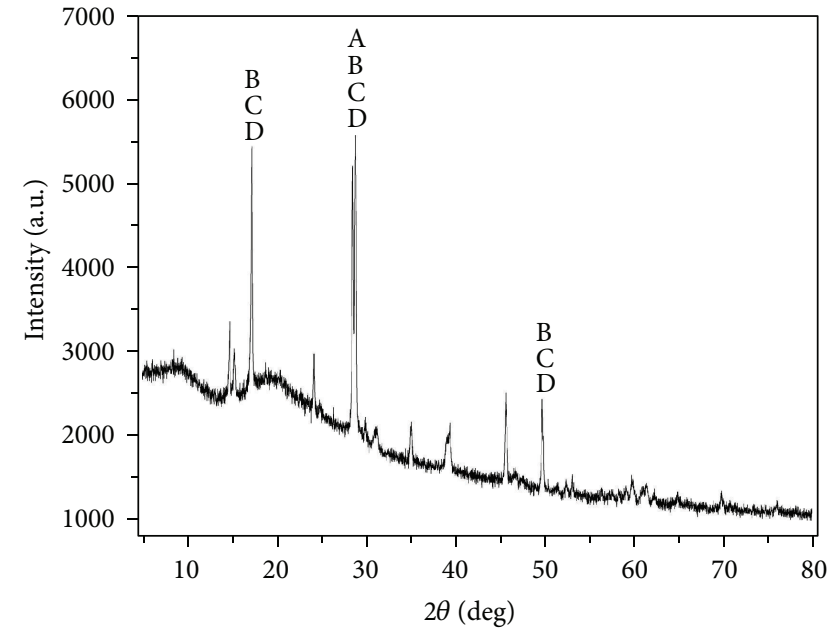

(a)

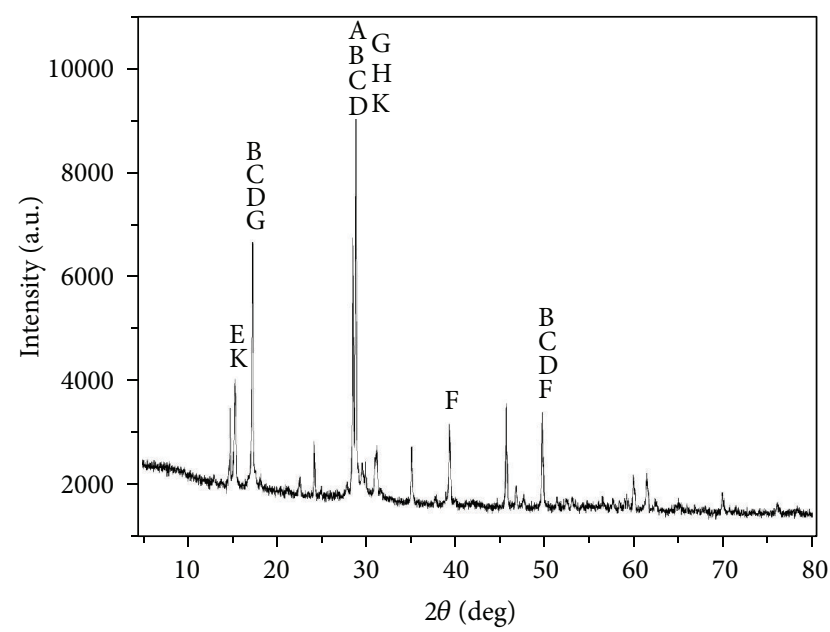

(b)

FIgURE 3: XRD patterns of arsenic precipitates observed on A. ferrooxidans BY-3 cells. The powder XRD analyses of the raw sample and the residual bioleaching were conducted on a multipurpose X-ray diffraction system (X'Pert-Pro MPD, Philips) with Cu K $\alpha$ radiation $(\lambda$ $=0.15406 \mathrm{~nm}$ ) operated at $40 \mathrm{kV}$ and $40 \mathrm{~mA}$. The diffraction patterns were obtained by scanning the sample in interval angles of $2 \theta$ from $5.0084^{\circ}$ to $79.9784^{\circ}$. Data analysis and phase identification were performed using the X'Pert High Score Plus software package version 2.2 (PANalytical B.V. Almelo, The Netherlands). (a) Pristine: A. ferrooxidans BY-3 in the medium without realgar. (b) As-loaded: A. ferrooxidans BY-3 in the medium with realgar. A: Magnetite $/ \mathrm{Fe}_{3} \mathrm{O}_{4}, \mathrm{~B}$ : jarosite, $\mathrm{C}$ : hydroniumjarosite, $\mathrm{D}$ : ammoniojarosite, E: arsenic sulfide/AsS, F: mackinawite/tetragonal FeS, G: ferric arsenate, $\mathrm{H}$ : potassium arsenate, and $\mathrm{K}$ : sodium hydrogen arsenite.

the corresponding functional groups were closely involved in the arsenic precipitation, especially the $-\mathrm{OH}$ and $-\mathrm{NH}$ groups, which experienced dramatic shifts as large as $112 \mathrm{~cm}^{-1}$. The interaction between the functional groups on the surface of the biomass and realgar is considered as a critical factor that avoided significant bacterial inhibition and facilitated the bioprecipitation process.

\section{Conclusion}

SEM, TEM, XRD, and FT-IR analysis were used to reveal the characteristics of arsenic precipitation. All the results confirmed that precipitation of arsenic with $A$. ferrooxidans and iron compound can decrease arsenic concentration in solution. Thus, arsenic concentrations in leaching solution of 


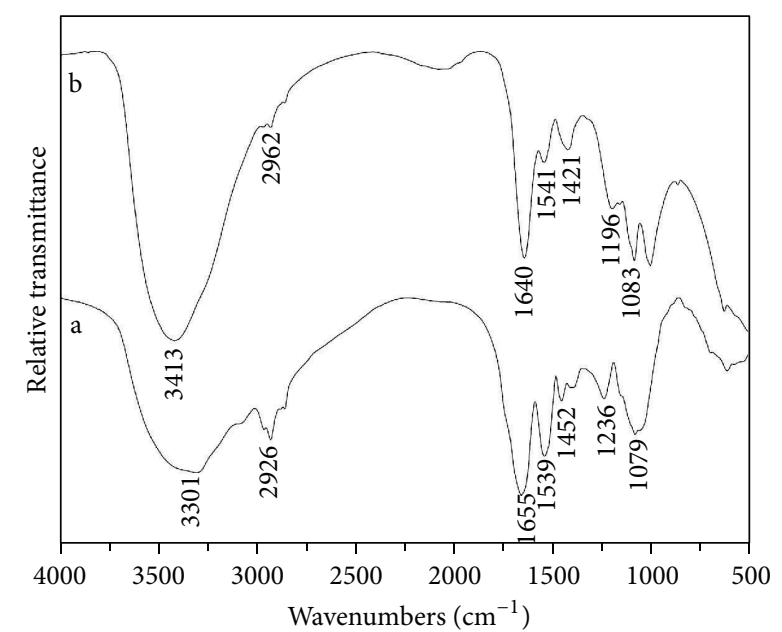

FIGURE 4: FT-IR difference spectra of A. ferrooxidans BY-3. The FT-IR spectra were recorded using a FT-IR (NEXUS 670, Thermo Nicolet, USA) over the wave number range of $500 \mathrm{~cm}^{-1}$ to $4000 \mathrm{~cm}^{-1}$ under ambient conditions. a: Pristine: A. ferrooxidans BY-3 in the medium without realgar. b: As-loaded: A. ferrooxidans BY-3 in the medium with realgar.

realgar are thought to be reduced through the precipitation of arsenic. This study demonstrates that the combined action of biologic and chemical absorbents may play important roles in arsenic precipitation during the process of leaching realgar by $A$. ferrooxidans.

\section{Conflict of Interests}

The authors declare that they have no conflict of interests.

\section{Acknowledgments}

This work was supported by Technology Program of Gansu Province (Grant nos. 2GS064-A43-019-02, 0708WCGA150, 0912TCYA025, 1004TCYA041, and 1207TCYA034), Open Project of Key Laboratory for Magnetism and Magnetic Materials of the Ministry of Education, Lanzhou University (Grant no. LZUMMM2010016), and the Fundamental Research Funds for the Central Universities (Grant no. lzujbky-2010-36).

\section{References}

[1] J. Wu, Y. Shao, J. Liu, G. Chen, and P. C. Ho, “The medicinal use of realgar $\left(\mathrm{As}_{4} \mathrm{~S}_{4}\right)$ and its recent development as an anticancer agent," Journal of Ethnopharmacology, vol. 135, no. 3, pp. 595602, 2011

[2] P. Baláž, M. Fabián, M. Pastorek, D. Cholujová, and J. Sedlák, "Mechanochemical preparation and anticancer effect of realgar As4S4 nanoparticles," Materials Letters, vol. 63, no. 17, pp. 1542$1544,2009$.

[3] P. Chen, L. Yan, F. Leng et al., "Bioleaching of realgar by Acidithiobacillus ferrooxidans using ferrous iron and elemental sulfur as the sole and mixed energy sources," Bioresource Technology, vol. 102, no. 3, pp. 3260-3267, 2011.
[4] B. Escobar, E. Huenupi, I. Godoy, and J. V. Wiertz, "Arsenic precipitation in the bioleaching of enargite by Sulfolobus BC at $70^{\circ}$ C", Biotechnology Letters, vol. 22, no. 3, pp. 205-209, 2000.

[5] M. P. Asta, J. Cama, M. Martínez, and J. Giménez, "Arsenic removal by goethite and jarosite in acidic conditions and its environmental implications," Journal of Hazardous Materials, vol. 171, no. 1-3, pp. 965-972, 2009.

[6] T. Türk, I. Alp, and H. Deveci, "Adsorption of As $(V)$ from water using nanomagnetite," Journal of Environmental Engineering, vol. 136, no. 4, pp. 399-404, 2010.

[7] F. Baillet, J.-P. Magnin, A. Cheruy, and P. Ozil, "Chromium precipitation by the acidophilic bacterium Thiobacillus ferrooxidans," Biotechnology Letters, vol. 20, no. 1, pp. 95-99, 1998.

[8] D. Mohan and C. U. Pittman Jr., "Arsenic removal from water/wastewater using adsorbents: a critical review," Journal of Hazardous Materials, vol. 142, no. 1-2, pp. 1-53, 2007.

[9] Chinese Pharmacopoeia Committee, Pharmacopoeia of the People's Republic of China, China People's Press, Beijing, China, 2010.

[10] M. P. Silverman and D. G. Lundgren, "Studies on the chemoautotrophic iron bacterium Ferrobacillus ferrooxidans. I. An improved medium and a harvesting procedure for securing high cell yields," Journal of bacteriology, vol. 77, no. 5, pp. 642647, 1959.

[11] J. Ayache, L. Beaunier, J. Boumendil, G. Ehret, and D. Laub, Sample Preparation Handbook For Transmission Electron Microscopy: Methodology, Springer, Berlin, Germany, 1st edition, 2010.

[12] L. Yan, H. Yin, S. Zhang, F. Leng, W. Nan, and H. Li, "Biosorption of inorganic and organic arsenic from aqueous solution by Acidithiobacillus ferrooxidans BY-3," Journal of Hazardous Materials, vol. 178, no. 1-3, pp. 209-217, 2010.

[13] R. González, J. C. Gentina, and F. Acevedo, "Attachment behaviour of Thiobacillus ferrooxidans cells to refractory gold concentrate particles," Biotechnology Letters, vol. 21, no. 8, pp. 715-718, 1999.

[14] P. Devasia, K. A. Natarajan, D. N. Sathyanarayana, and G. R. Rao, "Surface chemistry of Thiobacillus ferrooxidans relevant to adhesion on mineral surfaces," Applied and Environmental Microbiology, vol. 59, no. 12, pp. 4051-4055, 1993.

[15] J. Giménez, M. Martínez, J. de Pablo, M. Rovira, and L. Duro, "Arsenic sorption onto natural hematite, magnetite, and goethite," Journal of Hazardous Materials, vol. 141, no. 3, pp. 575580, 2007.

[16] D. Paktunc, J. Dutrizac, and V. Gertsman, "Synthesis and phase transformations involving scorodite, ferric arsenate and arsenical ferrihydrite: implications for arsenic mobility," Geochimica et Cosmochimica Acta, vol. 72, no. 11, pp. 2649-2672, 2008. 

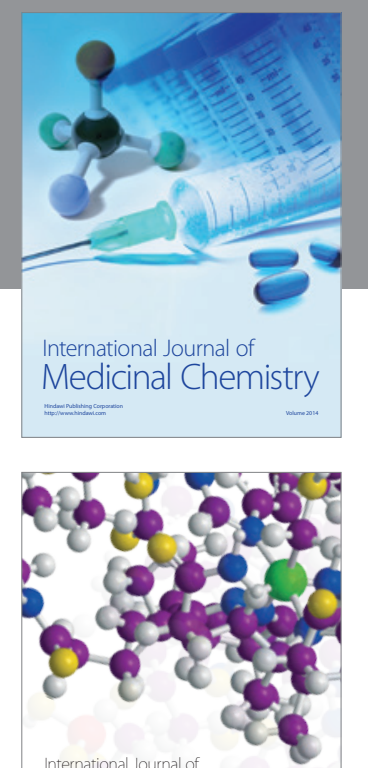

\section{Carbohydrate} Chemistry

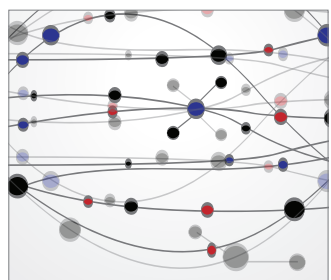

The Scientific World Journal
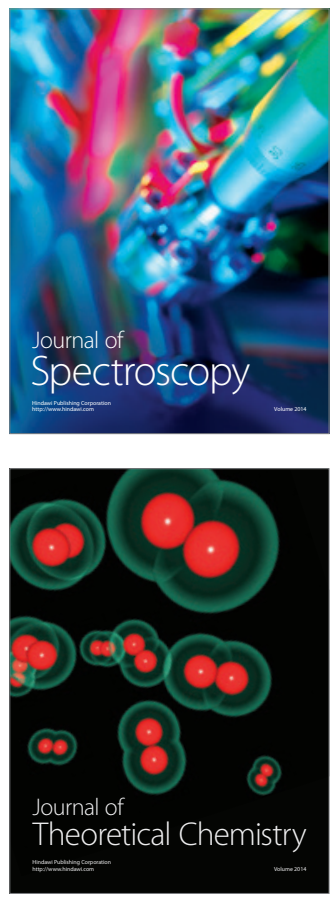
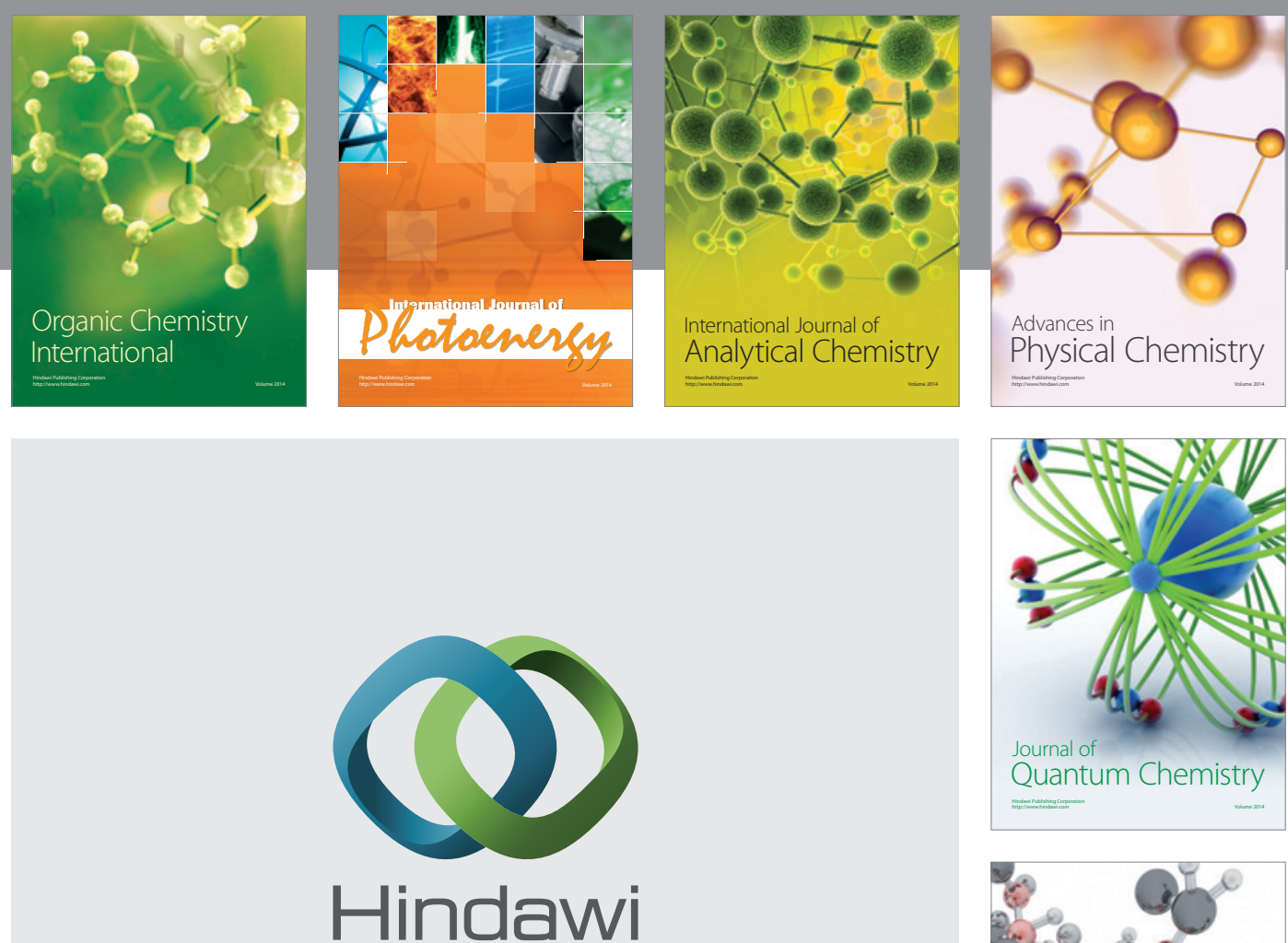

Submit your manuscripts at

http://www.hindawi.com

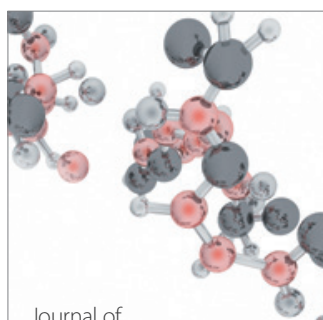

Analytical Methods

in Chemistry

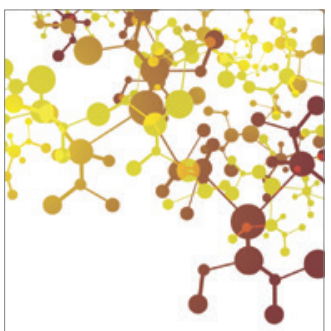

Journal of

Applied Chemistry

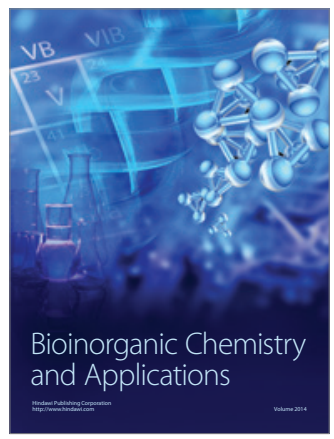

Inorganic Chemistry
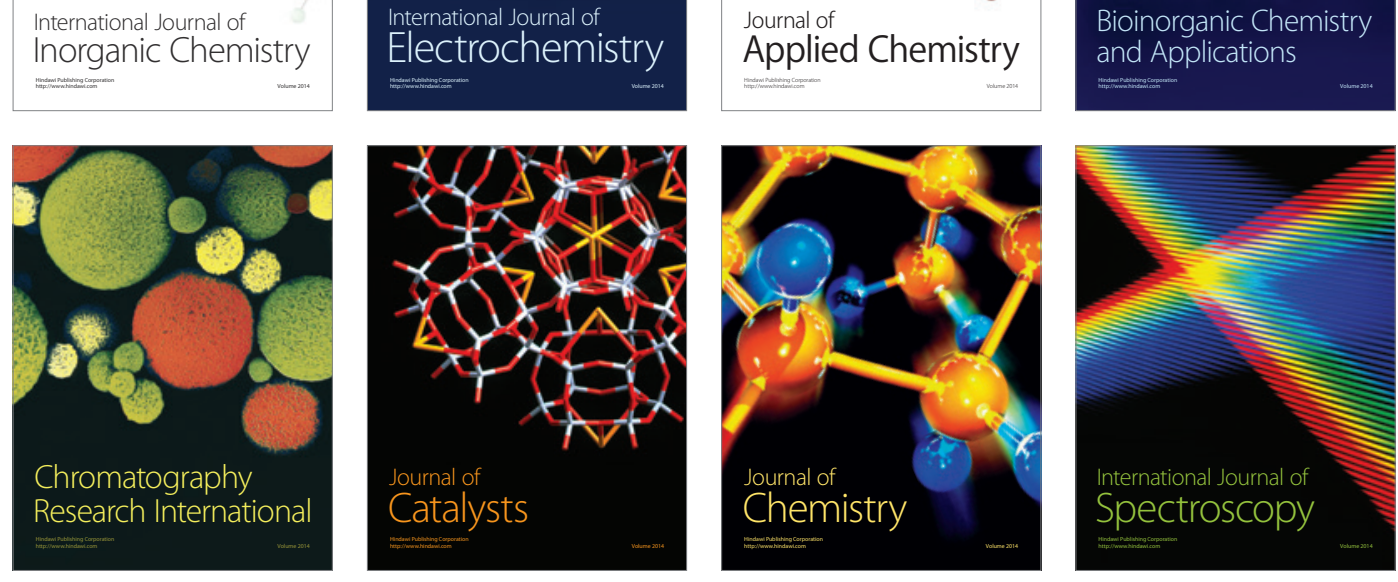